\title{
The Technological Impact on Objective Journalism Culture towards Democracy
}

\author{
Sri Syamsiyah LS, Sri Hastjarjo, Widodo Muktiyo and Prof. Pawito \\ Universitas Sebelas Maret, Surakarta, Indonesia \\ srisyamsiyah@student.uns.ac.id,sri.hastjarjo@staff.uns.ac.id,muktiyo@yahoo.com,pawito_palimin@staff.uns.ac.id
}

Keywords: Objectivity, technology, journalism culture, democracy.

\begin{abstract}
The technology impact on objective journalism culture towards press or media democracy is believed to have an important role in creating a democratic society (Gans: 2003). Hence, it is important to develop an objective press. The culture of objectivity should be developed and applied in journalism. As an informing agent, the press has to keep their objectivity in order to maintain factual values of the news they deliver. However, due to technological development, journalists seem no longer to be sole agents of information. As people can upload any kinds of information by themselves, objectivity is much needed to maintain the morality role of journalists as agents of information. This research focuses its study on the news objectivity to maintain democracy. Using qualitative research approach, the data were collected by interviewing editors-in-chief and journalists of several regional and local newspapers in the Province of Central Java, Indonesia. The research shows that objectivity is an important value to own by the media and its reporters. The development of technology also plays a major role in the changing of objective perspective and journalism practice that follows.
\end{abstract}

\section{INTRODUCTION}

The press has a major role in creating a democratic society. There are many concepts and elements of democracy that point to the concept of "rule by the people" (Campbell, 2008). The decision making by the society will also depend on the quality of information delivered by the press (Gans, 2003; Voltmer, 2007; Sonnemaker, 2015). With objective journalism culture, democracy is expected to preserve. Therefore, journalism culture within the press should be aligned with its role as a legitimate information agent (Kovach \& Rosentiel, 2014). One of the important values that must be maintained by journalists is objectivity (Streckfuss, 1990; Bennet, 2011). The value of objectivity becomes one crucial dimension of journalism culture (Hanitzsch, 2007).

Objectivity is closely related to the truth. Journalists and media should provide accurate and reliable news. Sometimes objectivity is substituted with the terms accuracy, fairness, balance, and truth (Bennet, 2011:195). McQuail (1992:184) proposes six elements that need to be considered when someone examine the news objectivity, i.e. (1) balance (covering all sides of an issue); (2) accuracy; (3) presenting all relevant points; (4) separating the facts and opinions; (5) minimizing the influence of individual opinion; and (6) avoiding devious objective. Hartley (2012:18) argues that there is a potential bias in the news due to the lack of objectivity. He refers to the news that was constructed by the facts representation.

The technology development gives impacts to many things such as journalism, democracy, and social institution (Franco, 2009; Pavlik, 2011). Internet technology allows people to give information easily that can lead to information overload-some called it as news overload. In such situation, news objectivity becomes more crucial. Smart use of technology could help in finding the solution (Renjith, 2017). One of the smart ways is perceiving news from many perspectives. To get unbiased news, journalists are supposed to cover not only one side of the facts, but also many others. 
Press has to give public discussion or debates space. The press is also expected to establish a forum to accommodate public opinions and criticisms to avoid stereotyping (McQuail, 1992:37). In this case, the technology could help them to realize it.

Schudson (in Hanitzsh, 2007) argues that journalists as an individual have his/her own values and attitudes that influence the process of reconstructing the facts into news. The mass media also has considerable influences to process the media contents production (Shoemaker \& Reese, 1996). Contents of the media do not blatantly represent facts as they are as they have been processed, interpreted, and reproduced by journalists and editors in the newsroom (Muktiyo, 2011).

This paper will observe how the culture of objective journalism is formed, while analyzing the formation of objective journalism culture and how to maintain it, how technology is utilized, either from the perspective of media organization or journalists.

\section{METHODOLOGY}

This research is using a qualitative approach with indepth interview as the data collecting method. Collecting data through interview was chosen in order to get the informants' perspective on the issues and to track down the evaluation of their own behaviours (Pawito, 2007). The informants for this study are journalists and editors-in-chief from regional and local print newspaper published in the Province of Central Java, Indonesia.

The interviews were conducted from July 2017 until May 2018 by incorporating two techniques: (1) direct interviews in which the researchers directly met the informants and interviewed them for around 30-90 minutes each; (2) interviews by email, which in some cases were followed up through a phone interview and social media WhatsApp messenger.

Table 1. List of Informants

\begin{tabular}{|l|l|l|}
\hline Name & \multicolumn{1}{|c|}{ Background } & Code \\
\hline Informant 1 & Editor-in-chief of Solopos & I1 \\
\hline Informant 2 & $\begin{array}{l}\text { Vice Editor-in-chief of } \\
\text { Radar Solo (Jawa Pos } \\
\text { Group) }\end{array}$ & I2 \\
\hline Informant 3 & $\begin{array}{l}\text { Managing Editor of Radar } \\
\text { Semarang }\end{array}$ & I3 \\
\hline Informant 4 & Editor-in-chief of Satelit Pos & I4 \\
\hline Informant 5 & $\begin{array}{l}\text { Editor-in-chief of Radar } \\
\text { Tegal (Jawa Pos Group) }\end{array}$ & I5 \\
\hline Informant 6 & Journalist of Radar & I6 \\
\hline
\end{tabular}

\begin{tabular}{|l|l|l|}
\hline & Semarang & \\
\hline Informant 7 & Journalist of Suara Merdeka & I7 \\
\hline Informant 8 & Journalist of Solopos & I8 \\
\hline Informant 9 & $\begin{array}{l}\text { Journalist of Radar } \\
\text { Semarang }\end{array}$ & I9 \\
\hline Informant 10 & Journalist Radar Semarang & I10 \\
\hline
\end{tabular}

\section{RESULT AND DISCUSSION}

\subsection{The meaning of objective journalism and democratic culture}

Journalism culture is defined as a set of values and practices in the journalistic world (Hanitzsch, 2007). Journalism culture is based on the value of objectivity that will bring about the objective journalism practices. Responding to questions about the meaning of objectivity, all informants agree that objectivity is the basis of journalism. The informants who work as a journalist said that the meaning of objectivity is not taking sides. As journalists, they should cover the news in a balanced way and based on facts, not only from one side but from many sides to find the truth.

\section{"We have to present complete news sources, which means not only covering both sides but all sides." (I3,2018, personal communication).}

The informants also acknowledge the relationship between objectivity in journalism practices and democratic society as the writing produced by journalists will influence the society. For example, Informant 3 (I3) argues that news objectivity has the tendency to make people be more honest with themselves and the others. Objectivity also encourages people to maintain democracy altogether. The culture of objective journalism is much needed as it helps to present the fact. Legitimate fact is one of the foundations for a democratic society.

\begin{abstract}
"The value and practice of journalists are shifting due to the technological development. In the past, people said that online media was of reader's choice, while the newspaper was of editor's choice. But now, I can say that the newspaper is in between the editor's choice and reader's choice due to technological change." (I1,2018, personal communication).
\end{abstract}

It will endorse the democracy as many opinions will be considered. However, Informant 1 said that although he had read many issues in social media, he 
did not easily accept them as they were. Mainstream media are now more credible thanks to its verification discipline that they maintain.

\subsection{Developing the culture of objective journalism}

Almost all informants who work as an editor-inchief stated that the construction of journalism culture among the journalists would be more effective if it was implemented as early as possible. Some informants even said that the efforts to develop the journalist's objective values was conducted since the recruitment process.

Informant 4 (I4) said that the journalism culture was built from the beginning. The decision to make good relation with sources to support his/her work was already considered since the first time he/she joined the media (I4, 2018, WhatsApp). This culture building has also implemented to journalists with zero experience. They will get the value transfer and journalistic practices directly from their seniors. The value transfer also takes place through meetings and training organized by the media company.

This early process is crucial to prevent journalists from being exploited to certain political interest and breaking their professional values.

\footnotetext{
"In my company, if an editor or a journalist joins any political party, he or she has to choose to resign from this company or resign from the political party." (I1, 2018, personal communication).
}

Another informant said that a journalist is not allowed to join any political party from the beginning. A journalist must resign from his/her position had they join a political party (I2, 2018, personal communication).

The decision to choose a political party or the media is important to prevent any political influence in the news making. Informant 5 (I5) said that politics could highly influence the journalism culture. It is important for journalists to understand that media should not accentuate any political views from a certain party.

The informants who work as a journalist said that they are not interested in joining political practices, although are dealing with political news every day. They realize that they have to remain objective as a journalist.

"One of the functions of the press is to inform. Therefore, the information transfer should be based on professionalism." (I9, 2017, personal communication).

He also added that a journalist must realize the consequence of his/her job and to always maintain his/her professionalism, so that he/she could not easily be influenced by any external factor.

The other informant said that his seniors or editors give him guidance during a crucial coverage. The efforts to maintain journalism culture includes training the journalist on using smart technology:

"The awareness in using technology must be implemented both to journalists and the media (editors). If the journalists don't have any access to social media, they will miss crucial information. Editors also have to monitor public groups in social media. If there is any information shared by netizen, editors could follow up the information and confirm it." (I2,2018, personal communication)

Value building is conducted through communication from the editors to journalists (I7, 2017, personal communication). As Shoemaker (1996) stated, the organizational level can affect news content. It is necessary to encourage the value of objectivity through media organizations.

\subsection{Value maintenance}

There are serious efforts done by the media organization to maintain the objective value at the earliest phase of journalistic career. Journalists must present independent report (Hastjarjo, 2017). In order to keep the journalistic practices on the right track, objective values need to be maintained, both by the editors and journalists.

Informant 2 (I2) said that although the owner or commissioner of his media company has become a cabinet minister, there is no pressure to support any political party or to intervene any news coverage and production. To maintain objectivity, a journalist should also go to the field to gather news facts.

"The editor or coverage coordinator will check whether the journalist really goes to the place where he or she was assigned to cover." (I2, 2018 , personal communication).

Informant 5 (I5) explained that he always gives an understanding about political impartiality to other journalists. Satelit Pos even have a special meeting to emphasize journalism techniques (I4 2018, WhatsApp).

Informant 2 (I2) stated that Radar Solo had given 
sufficient space to all political parties, although some of them were passive to the media. While Solopos, has its own standard value and system to examine news objectivity.

"There are editor meetings in the afternoon and evening, reporters' regular meeting, and evaluation meeting to maintain the standard of value." (I1, 2018, personal communication).

Furthermore, Informant 1 (I1) said that both the editors and journalists have the same interests and principles. A journalist cannot write a news story on his/her own will. An editor as a goalkeeper also cannot block or accentuate news stories without the right reasons (I1, 2018, personal communication).

Informant 8 (I8) explained the meaning of objectivity from the perspective of a journalist. He said that objectivity means not taking sides on a certain interest. They can try to find another source of information, instead of just coming from the politicians.

"With technology, we could conduct a crosscheck to find someone's track record so that the news could be more objective." (I8, 2018, personal communication).

Informant 7 (I7) said that in the local mayor or governor election, there are some candidates who actively ask the media to cover their activities. On the other side, there are also some candidates who are passive to the media.

The practice of maintaining objective values by journalists and editors, especially in the context of covering political events and political parties is in accordance with key concepts of democracy, namely equality, freedom, and control (Buhlman et al., 2008 cited in Campbell 2008). It has been cultivated by the journalists by providing full coverage of all parties equally.

\section{CONCLUSIONS}

From this research, we found that objectivity is an important value for democracy. Therefore, this value is being implemented to a journalist from the very beginning of the recruitment process. These objective value and practice constitute a culture of objective journalism. This culture should be maintained as many things could influence a journalist in constructing news stories, either from internal or external factors.

The technology has changed the perspective and the practice of journalism. Due to the interaction within social media, journalists can get to be more critical.

\section{REFERENCES}

Bennett, W. L. 2011. News: The Politics of Illusion, 9th. Ed. New York: Pearson.

Campbell, D. F. J. 2008. The Basic Concept for the Democracy Rangking of the Quality of Democracy, Vienna: Democracy Ranking.

Franco,Guillermo.2009. The Impact of Digital Technology on Journalism and Democracy in Latin America and The Caribbean, Knight Center for Journalism in the Americas at the University Foundations Media Program

Gans, H.J. 2003. Democracy and the News. Oxford: Oxford University Press.

Hanitzsch, T. 2007. Deconstructing Journalism Culture: Toward a Universal Theory. Communication Theory Vol. 17, No. 4, pp. 367-385.

Hartley, J. 2012. Communication, Cultural, and Media Studies: The Key Conceps. 3rd Ed. London: Routledge.

Hastjarjo, S. 2017. Local Journalism in the New Media Landschape: Opportunities and Challenges. Conference Paper. Proceeding of the 3rd International Conference on Social and Political Science (ICoSaPS) Dubai: Knowledge E.

Kovach, B., Rosentiel, T. 2014. The Element of Journalism 3rd Ed. New York: Three Rivers Press.

McQuail, D. 1992. Media Performance. Mass Communication and the Public Interest. London: Sage.

Muktiyo, W. 2011. Dinamika Media Lokal Dalam Mengkonstruksi Realitas Budaya Lokal Sebagai Sebuah Komoditas. Surakarta: Sebelas Maret University Press.

Pawito. 2007. Penelitian Komunikasi Kualitatif. Yogyakarta: Lkis.

Renjith, R. 2017.The Effect of Information Overload in Digital Media News Content, Communication and Media Studies, ISSN 2395-1559 Vol 6 No 1, Jan-Jun 2017 pp 73-85

Sambrook, R. 2012. Delivering Trust : Impartiality and Objectivity in the Digital Age. Report. London: Reuters Institute for the Study of Journalism.

Shoemaker, P.J., Reese, S.D. 1996. Mediating The Message. Theories of Influences of Mass Media Content. New York: Longman.

Sonnemaker, T. 2015. Objectivity and the Role of Journalism in Democratic Societies. Senior Theses Paper 1057. Claremont: Claremont McKenna College.

Streckfuss, R. 1990. Objectivity in Journalism: A Search and a Reassessment. Journalism Quartely Vol. 67 No. 4 (Winter) pp. 973-983.

Voltmer, K. 2006. The mass media and the dynamics of political communication in processes of democratization: An introduction. In Mass Media and Political Communication in New Democracies, Katrin Votmer (Ed.). New York: Routledge. 